\author{
Geology and geophysics
}

http://www.journalesgia.com

\title{
ANALYSIS OF SEDIMENTARY THICKNESS, VOLUMES AND GEOGRAPHIC EXTENT OF THE WORLD SEDIMENTARY BASINS
}

\author{
Abdullayev N.R. \\ Institute of Oil and Gas, Azerbaijan National Academy of Sciences \\ 9, F.Amirov ave.,Baku, AZ1000, Azerbaijan: Nazim_Abdullayev@hotmail.com
}

Keywords: sedimentary basins, South Caspian, sediment volumes,

sediment thickness, stratisphere

\begin{abstract}
Summary. Paper gives a brief overview of the sedimentary cover of the Earth and summarizes volumes of sediments and mass contained in the Earth Sedimentary layer (so called stratisphere). Using publically available data author also shows unique nature of the South Caspian Basin and demonstrates number of other rapidly subsiding basins that have an attenuated crust and thick sedimentary cover. The subsidence in basins results from crustal stretching, sedimentary and tectonic loading, and changes in the thickness or density of adjacent lithosphere and allows for sediments to be deposited. Sedimentary, crustal and lithospheric thickness correlation is discussed in this paper. Most of the world's basin volume and thicknesses vary according to the 80/20 (Pareto distribution) rule power law, where about $80 \%$ of the sediment volume has accumulated in the largest $20 \%$ of basins by volume. Lognormal correlation between basin size and thickness is observed for passive margins and extensional basins. Passive margins are about $4 \mathrm{~km}$ thick on average, foreland basins are about $3 \mathrm{~km}$ and cratonic sags are $2 \mathrm{~km}$ on average. South Caspian, however together with a number of other basins, is anomalous because of combination of flexural effect reducing its area and rapid Pliocene sedimentation rates. For example, more than 1.8 million cubic kilometres of net rock volume (or a solid sediment mass of $4.42 * 10^{\wedge} 9$ tons) have accumulated in the South Caspian basin since its inception; of which 595 thousand $\mathrm{km}^{3}$ was in Pliocene $(33 \%)$ and 221 thousand $\mathrm{km}^{3}$ in Quaternary. Volume and sedimentation rates in Pliocene in SCB exceed equivalent sedimentation rates in Bengal fan - largest sedimentary sink in the world.
\end{abstract}

(C) 2020 Earth Science Division, Azerbaijan National Academy of Sciences. All rights reserved.

\section{Introduction}

Knowledge about temporal and geographic distribution of sedimentary rocks on Earth comes from combinations made by Alexander Borisovich Ronov and Viktor Yefimovich Khain at the Vernadski Institute of Geochemistry of the academy of sciences of the USSR in Moscow. The compilation started in 1947 and included data on areas, volumes and masses of all continents except Antarctica and also from ocean basins. Thickness of the sedimentary basins of the world have been counted many times since that time most famously by Ronov (1993), Southam and Hay (1981), Kunin (1987), Berry and Wilkinson (1994). Most of the development has been summarized by Hay (1984), who gives very extensive review of distribution of mass-age of sediments on the continental blocks and additional data sediment that lies on the ocean floor based on Kunin (1987). Estimates from this study are within the range of estimates from previous studies.
Most of the world's sediment cover is in the sedimentary basins on the continents or continental margins with smaller portion of sediments on the oceanic crust. Sedimentary basins are regions of Earth of long-term subsidence creating accommodation space for infilling by sediments. The subsidence in the basins can result from crustal stretching, sedimentary and tectonic loading, and changes in the thickness or density of adjacent lithosphere. Grouping and analyzing sedimentary basins together one can find correlations amongst key geometric and volumetric parameters. The second objective of the study is to find anomalies or outliers such as South Caspian Basin in the distributions.This basin is unique in that it has much larger average thickness than others $(13 \mathrm{~km})$ and stands apart in any distributions.

\section{Data sources and method}

The data inputs for this study were derived from a number of open sources, including digitized sediment thickness maps from ICONS atlas project from 
Earthbyte website (https://www.earthbyte.org/Resources/ICONS/index.html), supplemented by more global sediment thickness map of the World compilation by Gabi Laske in UCSD: https://igppweb. ucsd.edu/ gabi/sediment.html. Sedimentary basin shapes were taken from CGG Robertson and ICONS basin shapes, where available. For the crustal and lithospheric thickness map I used updated global crustal model called LITHO1.0 https://igppweb. ucsd.edu/ gabi/litho1.0.html from Institute of Geophysics and Planetary Physics in UCSD. In addition some of sedimentary or crustal thicknesses were taken from more localized maps, such as ones for SCB from Abdullayev et al. (2015). The surface areas were measured directly from maps and no account was taken of the previous changes in basin shape, thus underestimating the original size of older basins. Mean thickness was estimated from the distribution of thickness values within geographical boundaries of the basin. Then the volume of the sediments in cubic meters was appraised by multiplying area by mean thickness. I calculated total volumes of sediments: net rock volumes calculations have been done for South Caspian only.

Fig.1 shows sediment thickness map of the world from which global sedimentary thicknesses and volumes were estimated. Study tabulates these for almost 900 sedimentary basins of the world located on continents on continental margins. Sedi- ments deposited on oceanic crust were excluded from calculations as well as basins of Antarctica for which data is limited. Higher quality estimates come from there where regional sedimentary thickness maps were available in ICON atlas: Africa, Arabian Peninsula, Arctic, Austria, Caspian Region, China, Central Europe, North America, South America, Siberia and South East Asia. The largest sedimentary sinks shown on the Fig. 1 are only in few areas of the globe.These sinks include South Caspian, PreCaspian, Mediterranean, Bengal Fan in Eurasia and Gulf of Mexico in America.

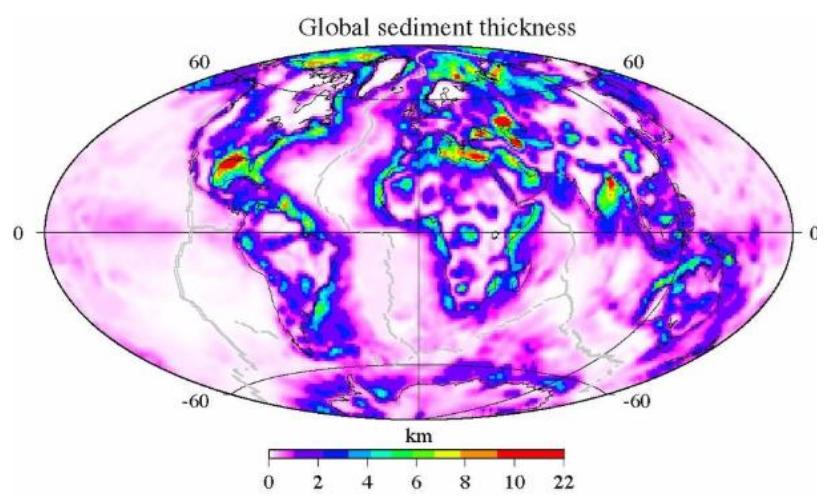

Fig. 1. World's sedimentary thickness map taken from this compilation by Gabi Laske in UCSD:

https://igppweb.ucsd.edu/ gabi/sediment.html

\section{Results: global view of crustal, sediment and lithosphere thickness}

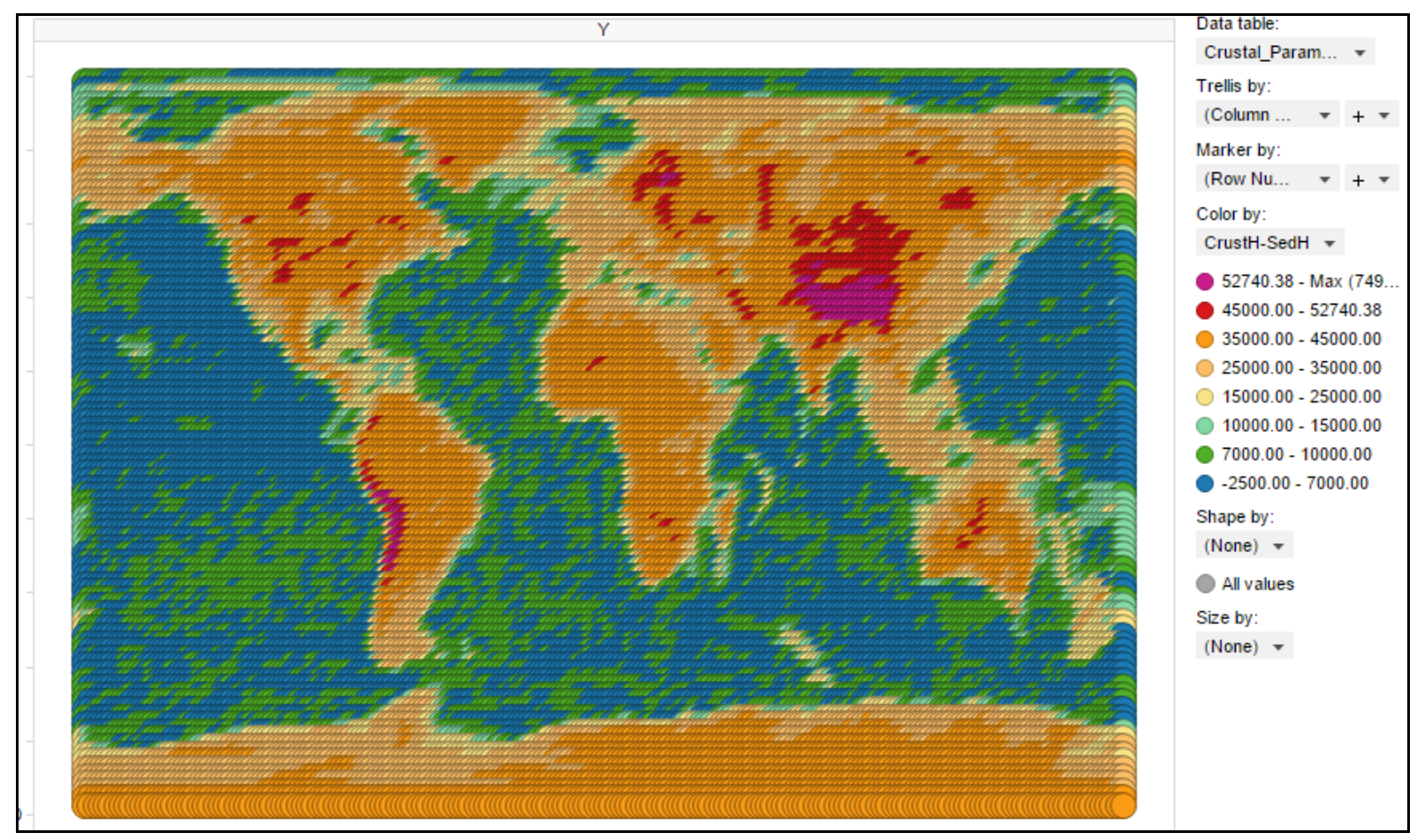

Fig. 2. Crustal thickness of consolidated crust (with sediment thickness excluded) in meters from the global crustal model LITHO1.0 https://igppweb.ucsd.edu/ gabi/litho1.0.html 
Using the data from LITHO1.0 models I made a map of crustal thickness (Fig. 2) and studied the relationships between different crustal parameters globally. Continental crustal thicknesses range between 30 to $70 \mathrm{~km}$ (Fig. 2) but with "average" thickness of around $35 \mathrm{~km}$ (Khain, 1982), which can be seen in Fig. 3A. The crust is divided into two layers: upper crust "granitic" and lower crust "basaltic" with the so-called upper crust granitic layer having thickness of around 20-25 km and density of 2700 $\mathrm{kg} / \mathrm{m}^{3}$ (Allen and Allen, 2013). The lower crust has mostly basaltic composition. Oceanic crust thickness is more uniform and is around $10 \mathrm{~km}$ (Fig. 3A and B). Crustal thickness distribution on Fig. 3A is bimodal where oceanic crust sits at one end with high frequency of occurrence (majority of the world's surface area are oceans) and continental crust has a range between 30 to $50 \mathrm{~km}$. Thickest sedimentary sinks $(>10 \mathrm{~km})$ are mostly associated with continental crust, except South Caspian Basin which is located over attenuated oceanic-type crust. Fig. 3B shows relationship between sedimentary thickness and crustal thickness as bounded by bell-shape of a Gaussian fit (Fig. 3B). Large sediment sinks like Pre-Caspian, Gulf of Mexico sit on the upper end of this curve fit. South Caspian Basin sits apart with much reduced crustal thickness and is the only large basin in LITHO1.0 model not fitting the curve.

Earth's lithosphere includes the crust and the uppermost mantle, which constitute the hard and rigid outer layer of the Earth (Allen and Allen, 2013). Oceanic lithosphere is typically about 50$140 \mathrm{~km}$ thick (but beneath the mid-ocean ridges is no thicker than the crust), while continental lithosphere has a range in thickness from about 40 to $240 \mathrm{~km}$ with an average of $150 \mathrm{~km}$ or so. Linear relationship exists between lithospheric thickness and crustal thickness for both oceanic and continental lithosphere as shown in Fig.3C. Sedimentary basins with a thick cover are developed on continental lithosphere that ranges between 100 and 220 $\mathrm{km}$ in thickness.

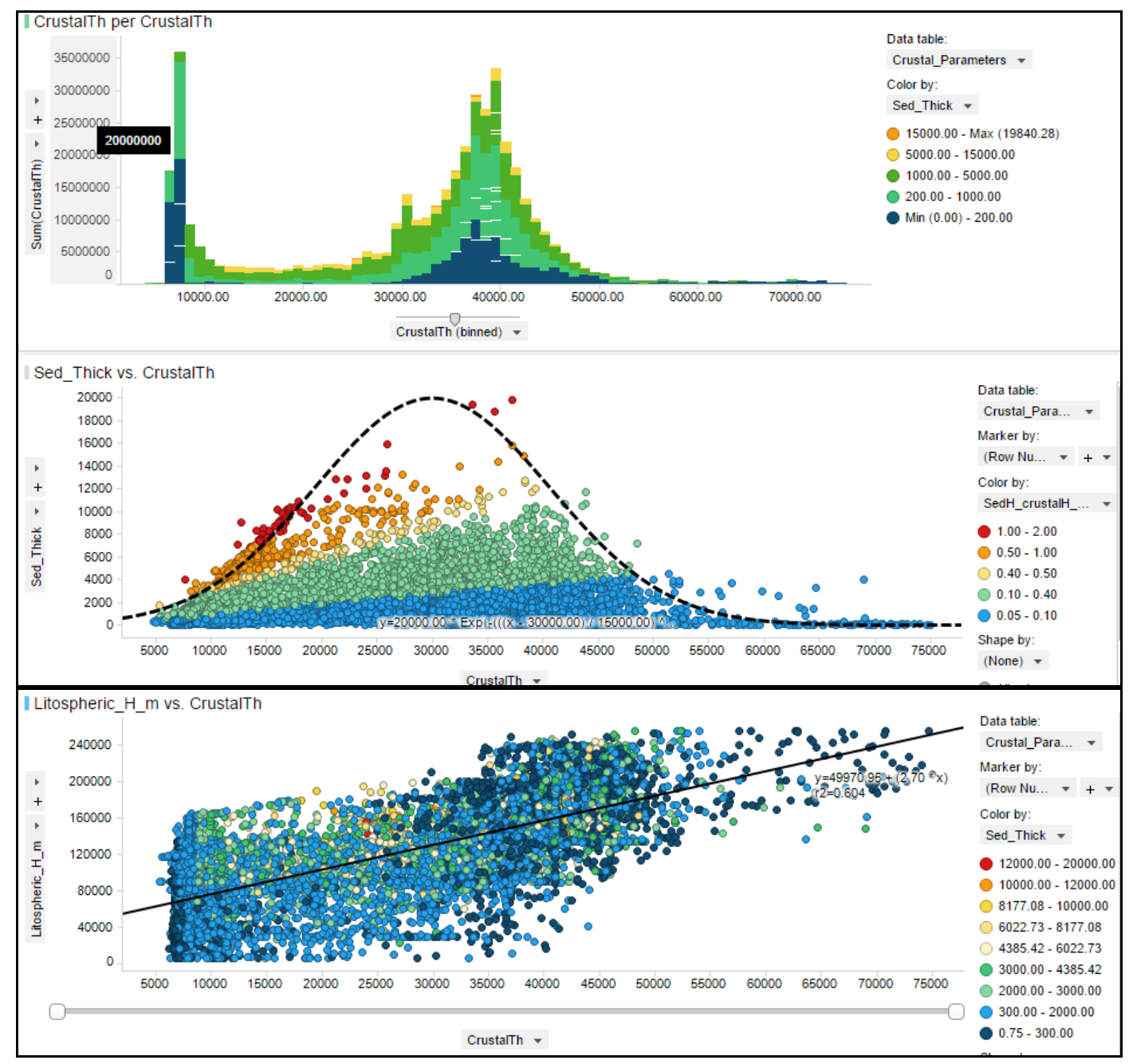

Fig. 3. Sedimentary thickness and crustal thickness distributions: A) crustal thickness distribution B) sediment thickness/crustal thickness ratio and C) lithospheric thickness vs. crustal thickness 
The ratio of sedimentary layer to non-sedimentary (consolidated) crustal thickness is mostly below 1.0 and exceeds 1.0 only in few basins, where sediments are very thick (Fig. 4). These basins are South Caspian, Pre-Caspian, Bengal Fan, Guyana-Amazon Fan, West Black Sea, East Mediterranean, Gulf of Mexico, Canadian Beaufort Basins, Laptev Sea, Santos Basin and few others. Fig. 4 shows the concentration of these basins, most of these basins are in the margins of the continents, except of the Pre-Caspian (interior continental sag). South Caspian and Black Sea are unique among them - in being basins with attenuated oceanic crust trapped between colliding continents. Again these basins typically have a relatively thin lithosphere of less than 100 kilometers thick.

\section{Results: volumes, thickness and area trends for sedimentary basins}

Most of up to 900 sedimentary basins are located on passive, active or rifted margins of the continents and interior of the continents such as cratonic sags, aulacogens or failed rifts. Most of the sediments are located in Eurasia (almost 50\%), followed by sediments in North America, Africa, South America and Australia (Fig. 5). Most of sediment accumulated during Phanerozoic was in mudstones and equally distributed in Paleozoic, Mesozoic and Cretaceous. Passive continental margins contain more than $40 \%$ of sediment volumes. Volumes estimates in this study are biased toward Cenozoic basins and less active margins, because older basins get consumed and have more modified surface areas.

Ronov (1993) compared four estimates of the total global mass of sedimentary rocks obtained by different authors. His estimate $(113 \mathrm{E}+21 \mathrm{~kg}$ or $11.8+18 \mathrm{~m}^{3}$ of which $7.6 \mathrm{E}+17 \mathrm{~m}^{3}$ are on the continents) coincided within 5\% to that of Southam and Hay (1981) who estimated $111.5 \mathrm{E}+21 \mathrm{~kg}$ and of Khain et al. (1982) who estimated $110.4 \mathrm{E}+21 \mathrm{~kg}$ ). Estimates $(97.0 \times 1021 \mathrm{~kg})$ in Kunin (1987), based on extrapolation of geophysical data on Eurasia to other continents differed from other estimates. My estimates using ICONS dataset are within $70 \%$ of the Ronov's estimates: $5.32 \mathrm{E}+17 \mathrm{~m}^{3}$ on the continents, excluding Antarctica. The discrepancies are probably in underestimation of some of the basin volumes outside detailed areas.

Out of this number Cenozoic rocks contain $1.79 \mathrm{E}+17 \mathrm{~m}^{3}$ (34\% of total), Cenozoic Eurasia is $7.73 \mathrm{E}+16 \mathrm{~m}^{3}$, and Cenozoic Northern Eurasia (Central, Eastern Europe, Caspian Region and Far East) is around $3.03 \mathrm{E}+16 \mathrm{~m}^{3}$ ( $8 \%$ of total).

There is a power law relationship between volumes and area of basins; their correlations are well defined by a logarithmic function and can be shown on Fig. 6.

(1) Area $(X)$ and Volume $(X)$ :

$\log _{10}(\mathrm{y})=4.11+\left(0.65 * \log _{10}(\mathrm{x})\right) \mathrm{R} 2=0.75$

(2) Mean Thickness (Y) and Volume (X):

$\left.\mathrm{Y}=0.28+\left((43.54-0.28) / 1.00-10^{0.32 *(18.55-\log 10(\mathrm{x}))}\right)\right)$

This relationship holds very true for the specific case of passive margin basins which occupy $40 \%$ of sediments. This can be true because they have very linear dependency between sediment wedge and area.The basins have relatively gradual transition between edges and the center of the basins and they are not generally bounded by steep faults creating rapid sediment thickness transitions.

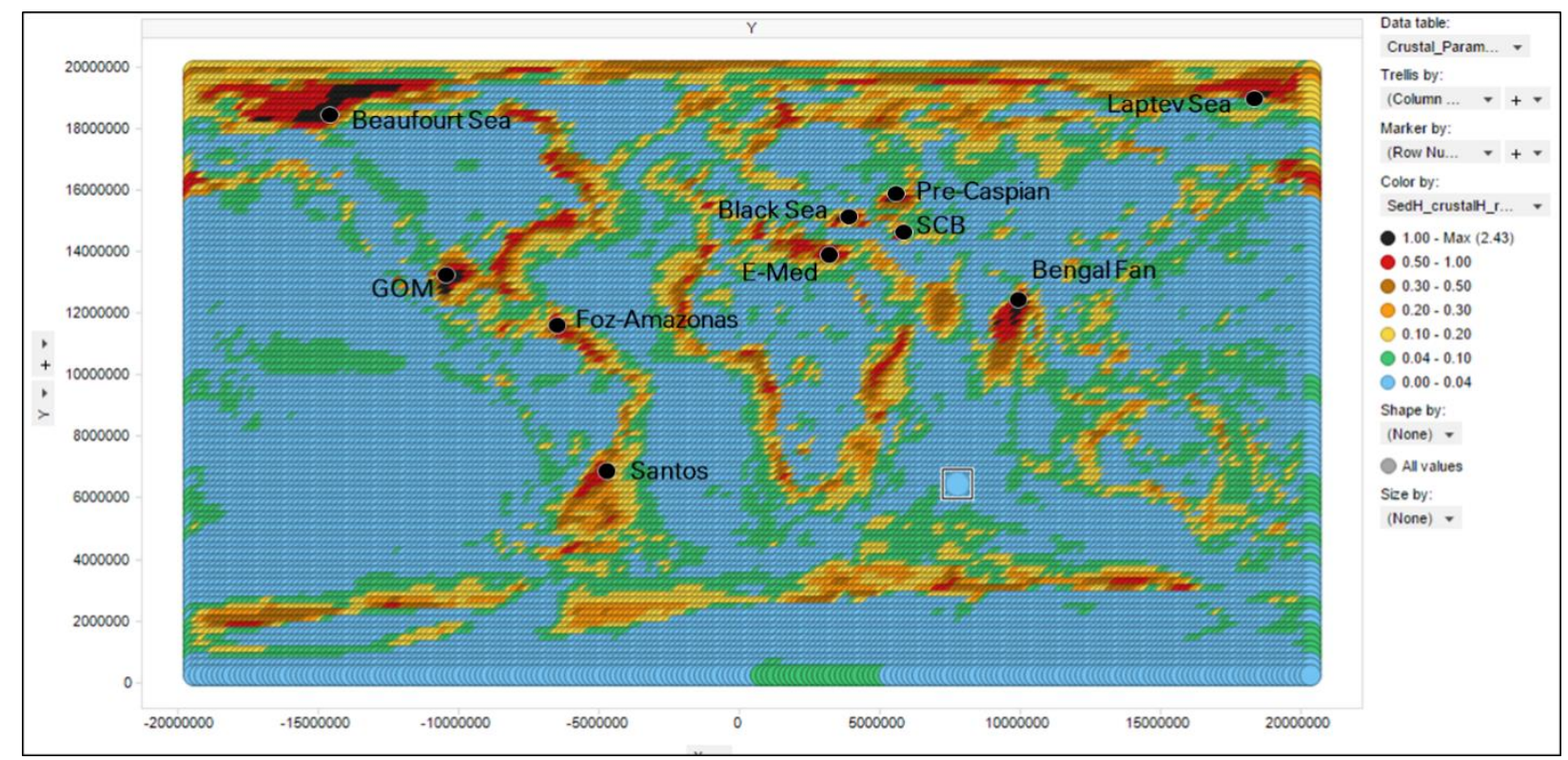

Fig. 4. Ratio of sedimentary thickness to non-sedimentary crustal thickness. Regions of low ratio denote little sedimentation. Red circles show the mega-basins that occupy most of the world where sediments are so thick that the ratio is larger than 1. 


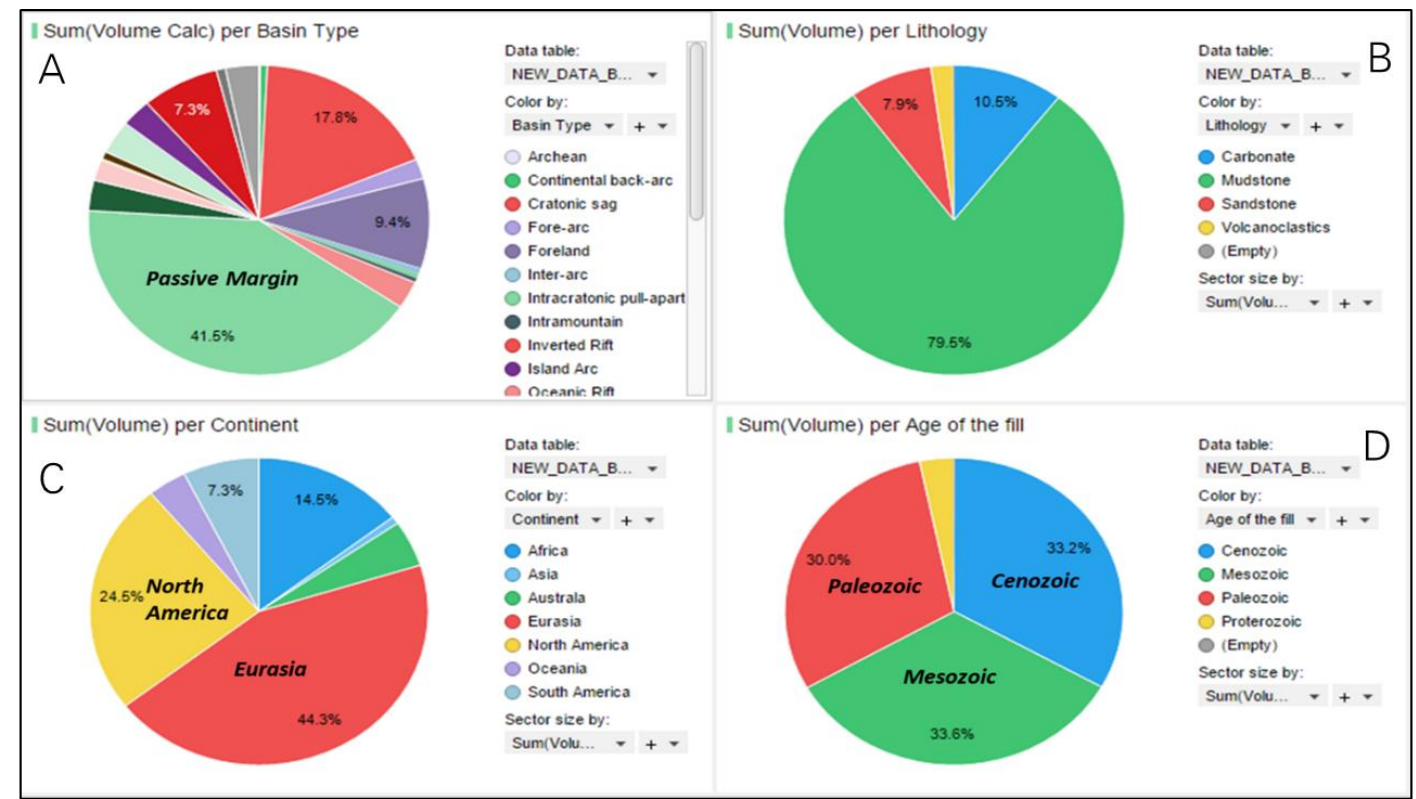

Fig. 5. Pie charts distributing sediment volume by basin type (A), lithology (B), continents (C), and sediment fill age (D)

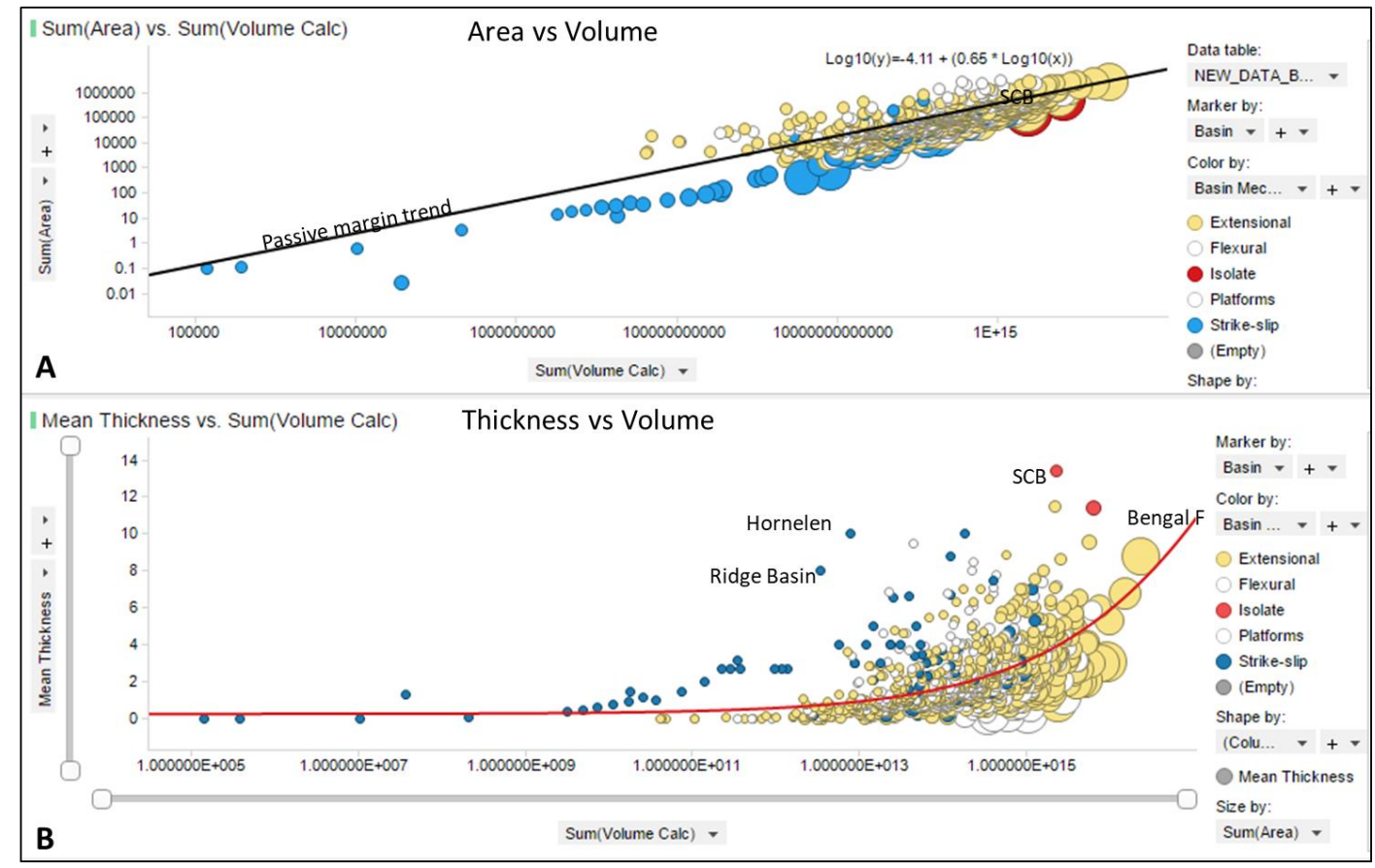

Fig. 6. Worldwide Basin Trends - A) Log/Log trend of the area vs. volume and B) lognormal trend of average thickness vs. volume $\left(\mathrm{km}^{3}\right)$. Passive margin trend is highlighted in upper two illustrations. Yellow circles show extensional basins, blue circles show strike-slip basins which deviate from the trend. Red is SCB and Pre-Caspian. Size of circles in Fig. 6A shows mean thickness and on Fig. 6B - present day area

All of the nearly 1000 basins are plotted in Fig. 6 which graphically shows distribution of basins by area, mean thickness and volume. Cumulatively it can be shown that the volume of sediments is spread out unevenly with 200 largest basins containing $80 \%$ of all the sediments in the world. It is also important to note that Bengal Fan is the most voluminous basin in the world (shown by the largest circle on Fig. 6B) and contains $5.4 \%$ of sediment volume calculated dominating all others. How thicknesses vary by ba- sin type can also be seen in Fig. 7, with thickest average and maximum thicknesses in the group I called "isolates" that includes large Eurasian basins surrounded by active orogenic belts and/or continental margins underlain by attenuated or simply oceanic type such South Caspian, Pre-Caspian both Black Sea basins. World's more than 140 passive margins by contrast are on average $3.2 \mathrm{~km}$ thick, intracratonic basins $-1.8 \mathrm{~km}$ thick, and deepwater arc-related basins are $1.5 \mathrm{~km}$ thick. 


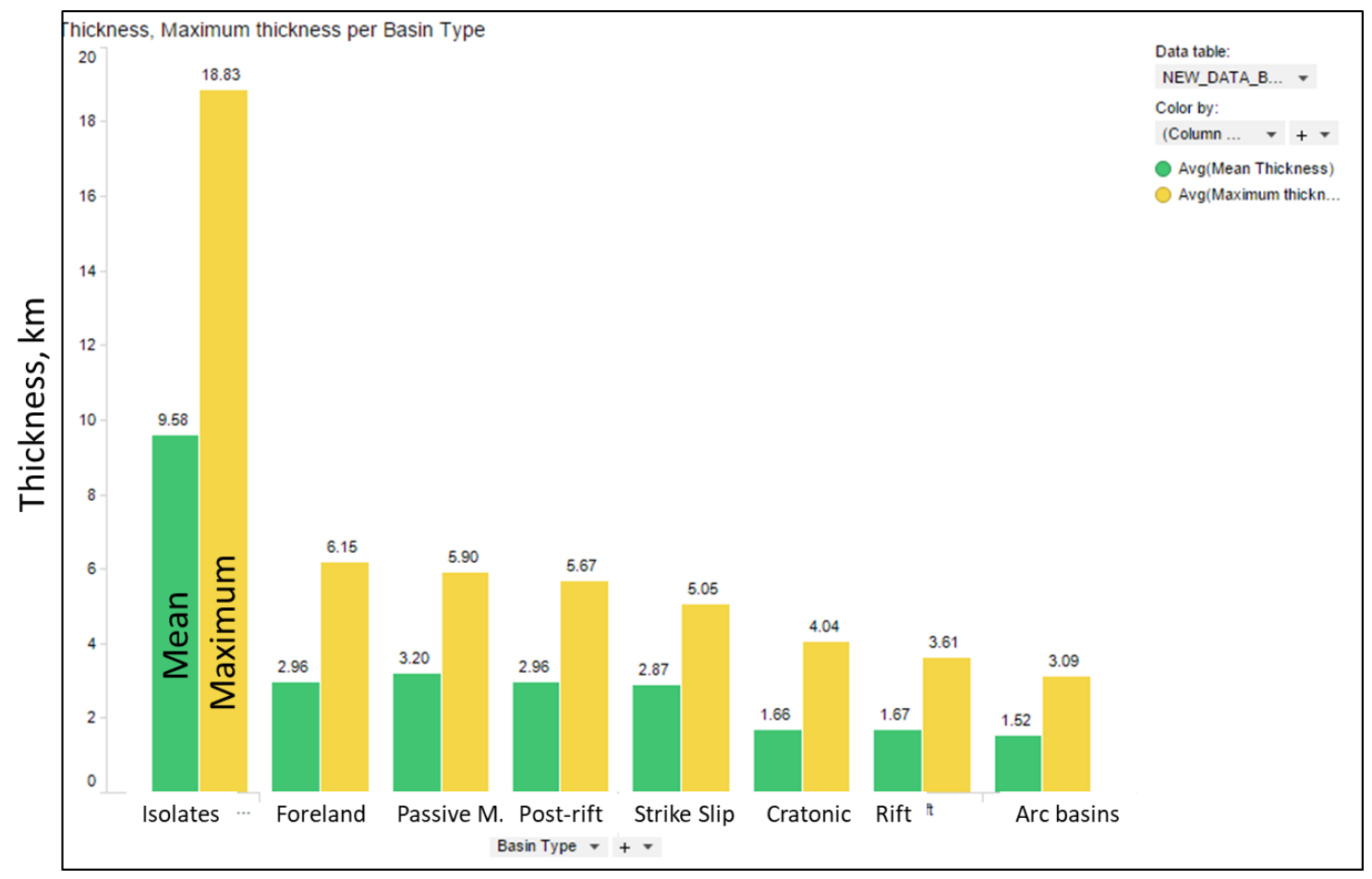

Fig. 7. (A) Distribution of mean and maximum thickness by key basin type

\section{South Caspian Basin anomaly}

Fig. 6 shows that two types of basins do not fit the derived trend: 1) some pull-apart basins in active areas and 2) "isolates" with trapped oceanic crust with South Caspian, most anomalous of all in terms of sedimentation rates and resulting thickness. SCB deviates significantly from other basins in a correlation of mean thickness to sediment volume (Fig. 6 and 7). It shows that with an average thickness of 13 $\mathrm{km}$ and a maximum of $26 \mathrm{~km} \mathrm{SCB}$ dominates all other sedimentary basins and does not fit passive margin trend from Equation (2). While there are some other, mostly pull-apart basins such as Ridge Basin in California (Allen and Allen, 2013) which have extremely thick average sediment thickness, they are small and sediment volume in them is insignificant. SCB in contrast is the $50^{\text {th }}$ sedimentary basin in the world. Pre-Caspian basin is also anomalously thick but most of the thickness is in Paleozoic and sedimentation rates are much lower.

More than $2.3 \mathrm{E}+15 \mathrm{~m}^{3}$ of sediments or $1.8 \mathrm{E}+15$ $\mathrm{m}^{3}$ of net rock volume (or a solid sediment mass of $4.42 * 10^{\wedge} 9$ tons with porosity excluded) have accumulated in the SCB since its inception; of which 595 thousand $\mathrm{km}^{3}$ was in Pliocene (33\%) and 221 thousand $\mathrm{km}^{3}$ in Quaternary (Abdullayev et al., 2015). The Pliocene age Productive Series represents significant increase in sedimentary volume after a base level fall in Early Pliocene. This increase occurred during a relatively short period of time between 3.6$4 \mathrm{Myr}$ and 2.71Myr (Abdullayev et al., 2018). It is interesting to observe that volume and sedimentation rates in Pliocene in SCB exceed equivalent sedimentation rates in Bengal Fan.

A way to explain anomalous sedimentary thickness of the South Caspian Basin is shown in Fig. 8. I see three key reasons for the anomaly. Firstly, the sediment volume in SCB is anomalous because oceanic-type crust that underlies would allow for excess subsidence when loaded by sediments.

Secondly, there are extremely high sedimentation rates creating this sediment loading. This happens during Pliocene Productive Series (PS) - a unique time when after a base-level fall and an isolation of the basin, more than 5 kilometers of sediments were deposited during 1 million years as a result of integration of large part of Eurasian river drainage into the SCB (Abdullayev et al., 2018). If the extreme sedimentation rates of PS were to be substituted by much smaller pre-Pliocene ones (at $300 \mathrm{~m} / \mathrm{Mya}$ ) then mean thickness would be reduced from 13.4 to $9 \mathrm{~km}$ much smaller but still high compared to the passive-margin trend (Fig. 8).

Thirdly, the present basin area is too small for its thickness. The basin in the past must have been aerially larger and was diminished as a result of significant shortening starting from Oligocene. If one assumes that SCB retained its volume inside the calculated shapes then in order to match the average trend line (pre-shortening) the area would have to be 2.5 times larger and mean thickness would have to be reduced to $3.7 \mathrm{~km}$. 
Geology and geophysics

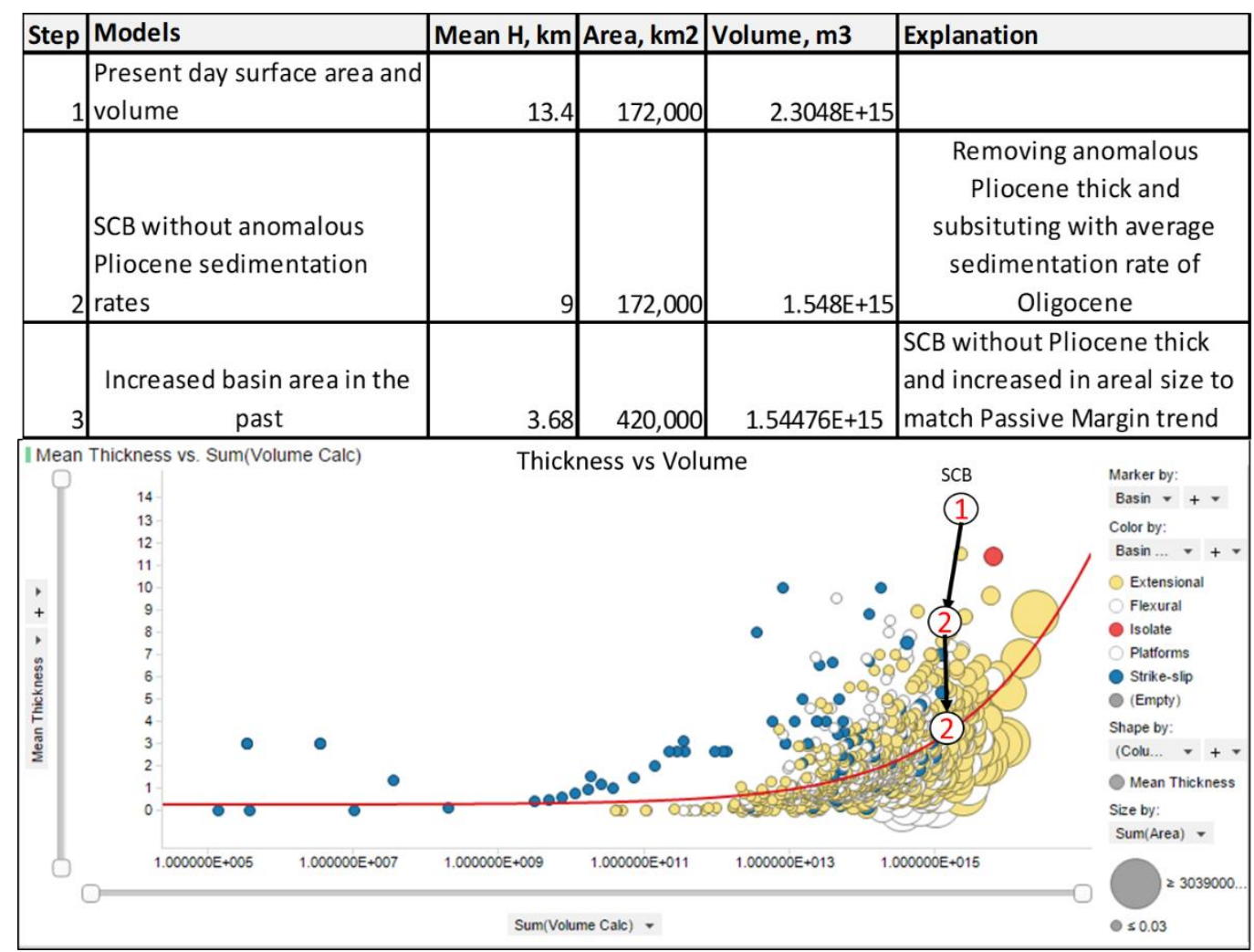

Fig. 8. Mean thickness vs. volume trend and three steps to explain anomalous behavior of the South Caspian Basin

\section{Conclusion}

The study estimated the volume within more than 900 sedimentary basins of the world on the continents and continental margins, excluding Antarctica with a total figure of $5.32 \mathrm{E}+17 \mathrm{~m}^{3}$.The study found that basins follow well behaved trends associated with the power law regression based on passive margins which in total make $40 \%$ of all sedimentary volumes. Average thickness of a basin is around 3 $\mathrm{km}$, typical of passive margins and forelands. Outside that trend there are some outliers, mostly pull apart basins or basins with unusually thick sedimentary pile surrounded by active orogens. Chief among anomalous basins is South Caspian Basin with its anomalous sedimentary thickness and Pliocene age extremely high depositional rates.

\section{LITERATURE}

Abdullayev N.R., Kadirov F., Guliyev I.S. Subsidence history and basin-fill evolution in the South Caspian Basin from geophysical mapping, flexural backstripping, forward lithospheric modelling and gravity modelling. Geological Society, London, Special Publication, V. 427, 2015, pp. 175-196, https://doi.org/10.1144/SP427.5

Abdullayev N.R., Weber J., Aliyeva E. et al. Detrital zircon and apatite constraints on depositional ages, sedimentation rates and provenance: Pliocene Productive Series, South Caspian Basin, Azerbaijan. Basin Res., V. 30, No. 5, 2018, pp.1-28.

Allen Ph.A., Allen J.R. Basin Analysis. Hoboken, NJ: WileyBlackwell, XII, 2013, 619 p.
Increase in sediment volume and sedimentation rates in South Caspian of this period are related to integration of the Eurasian river drainage into this small basin. This was coeval to increase in sedimentation rates recorded last 2 to $4 \mathrm{Myr}$ around a globe in a variety of settings, implying increasing erosional rates related to a change from a period of climatic stability to a more variable period of frequent and abrupt changes in climate. Reasons for such increase are hotly debated with two points of view - global uplift or climatic changes, after the onset of Northern Hemisphere glaciation. South Caspian Basin captured about $9 \%$ of sediment volume of Northern Eurasia. Understanding the history of basin fill of this volume, the provenance of sediment and key causes behind sediment input into the basin will shed light in global climate patterns in Northern Hemisphere.

\section{REFERENCES}

Abdullayev N.R., Kadirov F., Guliyev I.S. Subsidence history and basin-fill evolution in the South Caspian Basin from geophysical mapping, flexural backstripping, forward lithospheric modelling and gravity modelling. Geological Society, London, Special Publication, V. 427, 2015, pp. 175-196, https://doi.org/10.1144/SP427.5 Abdullayev N.R., Weber J., Aliyeva E. et al. Detrital zircon and apatite constraints on depositional ages, sedimentation rates and provenance: Pliocene Productive Series, South Caspian Basin, Azerbaijan. Basin Res., V. 30, No. 5, 2018, pp. 1-28. Allen Ph.A., Allen J.R. Basin Analysis. Hoboken, NJ: WileyBlackwell, XII, 2013, 619 p. 
Berry J.P., Wilkinson B.H. Paleoclimatic and tectonic control on the accumulation of North American cratonic sediment Geol. Soc. Am. Bull., V. 106, 1994, pp. 855-865.

Laske G. A global digital map of sediment thickness. University of California San Diega, Institute of Geophysics and Planetary Physics, USA, https://igppweb.ucsd.edu/ gabi/ sediment.html

Hay W.W. Pleistocene-Holocene fluxes are not the Earth's norm. In: Hay W., Usselman T. (eds) - Material fluxes on the surface of the Earth: studies in geophysics. National Academy Press. Washington, D.C., 1994, pp. 15-27.

Southam J.R., Hay W.W. Global sedimentary mass balance and sea level changes. In: Emiliani C. (ed.) - The Sea, V. 7. The Oceanic Lithosphere. Wiley-Interscience. New York, 1981, pp. 1617-1684.

Kunin N.Y. Distribution of sedimentary basins of Eurasia and the volume of the Earth's sedimentosphere. Int. Geol. Rev., V. 29, No. 11, 1987, pp. 1257-1264.

Ронов А.Б. Стратисфера или осадочная оболочка Земли. Наука. Москва, 1993, 143 с.

Хаин В.Е., Левин Л.Е., Тулиани Л.И. Некоторые физические параметры глобальной структуры Земли. Геотектоника, Т. 16, 1982, с. 443-453.
Berry J.P., Wilkinson B.H. Paleoclimatic and tectonic control on the accumulation of North American cratonic sediment. Geol. Soc. Am. Bull., V. 106, 1994, pp. 855-865.

Laske G. A global digital map of sediment thickness. University of California San Diega, Institute of Geophysics and Planetary Physics, USA, https://igppweb.ucsd.edu/ gabi/ sediment.html

Hay W.W. Pleistocene-Holocene fluxes are not the Earth's norm. In: Hay W., Usselman T. (eds) - Material fluxes on the surface of the Earth: studies in geophysics. National Academy Press. Washington, D.C., 1994, pp. 15-27.

Khain V.E., Levin L.E., Tuliani L.I. Some physical parameters of global structure of the Earth. Geotectonics, V. 16, 1982, pp. 443-453 (in Russian).

Kunin N.Y. Distribution of sedimentary basins of Eurasia and the volume of the Earth's sedimentosphere. Int. Geol. Rev., V. 29 , No. 11,1987 , pp. 1257-1264.

Ronov A.B. Stratisphere or Earth's sedimentary shell. Nauka. Moscow, 1993, 143 p. (in Russian).

Southam J.R., Hay W.W. Global sedimentary mass balance and sea level changes. In: Emiliani C. (ed.) - The Sea, V. 7, The Oceanic Lithosphere. Wiley-Interscience. New York, 1981, pp. 1617-1684.

\title{
АНАЛИЗ МОЩНОСТЕЙ, ОБЪЕМОВ И ГЕОГРАФИЧЕСКОЙ РАСПРОСТРАНЕННОСТИ ОСАДОЧНОГО ЧЕХЛА БАССЕЙНОВ МИРА
}

\author{
Абдуллаев Н.P. \\ Институт нефти и газа НАН Азербайджана \\ AZ1000, Баку, ул.Ф.Амирова, 9: Nazim_Abdullayev@hotmail.com
}

\begin{abstract}
Резюме. В статье дается краткий обзор по осадочному чехлу Земли и обобщаются объемы и массы осадков, находящихся в недрах стратисферы (осадочного слоя нашей планеты). Используя общедоступные данные из различных источников, автор показывает, насколько уникален Южно-Каспийский бассейн (ЮКВ), и приводит примеры нескольких других быстро погружающихся бассейнов с утоненной корой и мощным осадочным слоем. Погружение бассейна вызвано расширением коры, тектонической и осадочной нагрузкой, а также изменением мощности и плотности литосферы, что создает условия для накопления осадков. В статье показано, что объемы осадков в осадочном чехле меняются согласно правилу Парето (так называемое правило 80/20), поскольку $80 \%$ процентов всего объема осадков содержатся в самых больших по объему $20 \%$ бассейнов мира. Логарифмическая зависимость между размером бассейна и его объемом особенно четко наблюдается в бассейнах пассивных окраин и бассейнах растяжения (рифтах и вертикального погружения). Бассейны пассивных окраин в целом более распространены по миру, обладая до $40 \%$ всей мощности осадков мира. Пассивные окраины характеризуются в среднем мощностью 4 км, бассейны форланда -3 км, а межкратоновые впадины - менее 2 км. Южно-Каспийский бассейн вместе с другими быстропогружающимися и ограниченными по площади бассейнами мира является определенно аномальным из-за сочетания флексурного эффекта, уменьшившего его территорию, и быстрого осадконакопления в плиоцене. Так, более чем 1.8 миллионов кубометров осадков (или масса осадков весом 4.42*10^9 тонн) было накоплено в ЮжноКаспийском бассейне со времен его зарождения, из них 595 тысяч кубометров отложились в плиоцене (33\%), а 221 тысяча кубометров осадков - в четвертичное время. Объем и скорости осадконакопления в плиоцене даже превышают таковые в Бенгальском заливе - самом объемном осадочном бассейне мира, в котором находится более 5\% всех осадков мира.

Ключевые слова: осадочные бассейны, Южный Каспий, объемы осадков, стратисфера
\end{abstract}

\section{DÜNYA HÖVZəLəRINIIN ÇÖKÜNTÜ ÖRTÜYÜNÜN QALINLIQLARI, HəCMLORI Və COĞRAFI YAYILMASININ TOHLILII}

\author{
Abdullayev N.R. \\ AMEA Neft Va Gaz Institutu \\ AZ1000, Bakışəh., F.Omirov küç.,9: Nazim_Abdullayev@hotmail.com
}

Xülasə. Məqalədə Yerin çöküntü örtüyünün qısa icmalını, eləcə də çöküntülərin həcmi və onların Yerin çöküntü layında (Stratisfera) kütləsinin hesablamasını təqdim edilir. Müəllif dərc olunmuş məlumatları toplayaraq Cənubi Xəzər hövzəsinin unikallığını, eləcə də nazikləşmiş qabığa və qalın çöküntü örtüyünə malik olan bir sıra digər hövzələri təhlil edir. Hövzələrdə çökmə prosesi qabığın dartılması, çöküntü və tektonik yüklənmə, litosferin qalınlığı və ya sıxlığının dəyişilməsi əmələ gələn çöküntülərin toplanmasına imkan yaradır. Məqalədə çöküntü, qabıq və litosfer nisbəti müzakirə edilir. Dünyanın əksər hövzələrində həcm və qalınlıq 80/20 qanuna əsasən (Pareto paylaşması) ayrılır; beləliklə, çöküntülərin $80 \%$-i həcmə görə $20 \%$ təșkil edən hövzələrdə yerləşir. Hövzənin ölçüsü və qalınlığı arasındakı loqarifmik nisbət daha yaxşı passiv kənarlar və uzadılmış hövzələrdə müşahidə edilir. Passiv kənarlar (passive margins) ən həcmli olaraq (ümumi həcmin 40\%-ni təşkil edir) qalınlığ orta hesabla 4 $\mathrm{km}$ təşkil edir, forland hövzələri $3 \mathrm{~km}$ yaxın və kratonik depressiyalar isə orta hesabla $2 \mathrm{~km}$ təşkil edir. Cənubi Xəzər, bir sıra di- 


\section{Geology and geophysics}

gər hövzələrlə birgə ərazisinin azaldan fleksural effektlərin kombinasiyası və yüksək Pliosen çöküntü sürəti ilə əlaqədar anomallıq nümaiş etdirir. Cənubi Xəzər hövzəsinin yaranmasından başlayaraq, hövzədə 1.8 milyon kub kilometr həcmində xalis (netto) çöküntülər toplanmışdır (və ya $4.42 * 10^{\wedge} 9$ ton olan bərk çöküntü kütləsi). Onlardan həcmi $595000 \mathrm{~km}^{3}$ çöküntülər Pliosenə (33\%), $221000 \mathrm{~km}^{3}$ isə Pleystosen dövrünə təsadüf edir. Pliosendə Cənubi Xəzər hövzəsində çöküntülərin həcmi və cöküntu toplanma sürətləri hətta Dünyanın ən geniş çöküntülü Benqal fendakı çöküntü sürətlərini aşmışdır.

Açar sözlor: cöküntü hövzalari, Conubi Xəzər Hövzasi, çöküntü haçmi, stratisfera 